Author has nothing to disclose with regard to commercial support.

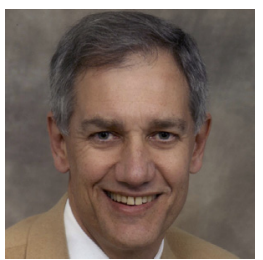

\section{EARLY MORTALITY IS INHERENTLY INACCURATE AS A QUALITY MARKER FOR CONGENITAL HEART SURGERY}

\section{To the Editor:}

In their Expert Opinion, Broberg and colleagues ${ }^{1}$ have used the example of the arterial switch procedure to illustrate the ethical dilemma of introducing a new surgical procedure (the arterial switch procedure) when established procedures are available that carry acceptably low early hospital mortalities (Mustard and Senning procedures). When Castaneda and colleagues ${ }^{2}$ introduced the primary neonatal arterial switch procedure in 1983, the higher early mortality of the new procedure was a highly contentious issue that was widely debated. The justification for introduction of the arterial switch procedure, which was the first elective neonatal surgical procedure with a potentially higher early mortality than alternatives performed later in infancy, was simple: the long-term consequences of an atrial level procedure were already becoming apparent and were likely to become more troublesome with time, leading to decreased quality of life, multiple reoperations, and reduced long-term survival. As Broberg and colleagues ${ }^{1}$ have documented, this justification, which was initially theoretic, did indeed prove to be correct.

Debate regarding the ethical dilemma of introducing the neonatal arterial switch led to the first prospective study conducted by the Congenital Heart Surgeons Society in the mid 1980s. ${ }^{3}$ The superiority of the arterial switch emerged, but only because the study design did not focus on early mortality as a primary end point. The primary end point was survival at 1 year of age for all patients with transposition of the great arteries admitted to participating hospitals in the first 2 weeks after birth. Although the early mortality was indeed somewhat higher

The Editor welcomes submissions for possible publication in the Letters to the Editor section that consist of commentary on an article published in the Journal or other relevant issues. Authors should: • Include no more than 500 words of text, three authors, and five references. • Type with double-spacing. • See http://jtcs.ctsnetjournals.org/ misc/ifora.shtml for detailed submission instructions. • Submit the letter electronically via jtcvs.editorialmanager.com. Letters commenting on an article published in the JTCVS will be considered if they are received within 6 weeks of the time the article was published. Authors of the article being commented on will be given an opportunity of offer a timely response ( 2 weeks) to the letter. Authors of letters will be notified that the letter has been received. Unpublished letters cannot be returned. with the arterial switch procedure, the overall survival at 1 year was also higher with the arterial switch approach. Early mortality failed to capture deaths that occurred in the interim between an initial balloon septostomy and a later atrial-level procedure. On the other hand, essentially all deaths were recorded as early deaths in the arterial switch group, because this procedure was performed in the neonatal period.

It is critically important that congenital surgeons abandon 30-day in-hospital mortality as a quality marker, because it fails to capture preoperative mortality and interim mortality when an initial palliative procedure is performed. A continuing focus on early mortality as a quality marker provides an incentive to congenital cardiac surgeons and hospitals to regress to an outdated 2-stage palliative approach that does not capture all mortality and furthermore inflates the denominator of number of procedures. Early mortality may be adequate as a quality marker for adult cardiac surgery, because there are rarely palliative surgical options, and long-term survival is less relevant to an elderly population. Parents of neonates with congenital heart disease appropriately focus on long-term quality of life for their children, freedom from multiple operations, and long-term survival. These are the quality indicators that should determine which surgical approach congenital teams take, rather than early mortality.

\section{Richard A. Jonas, MD \\ Cardiac Surgery \\ Children's National Medical Center \\ Children's National Heart Institute \\ Washington, DC}

\section{References}

1. Broberg CS, Shen I, Menashe V, Starr A. Emergence of the arterial switch procedure for transposition of the great arteries and the potential cost of surgical innovation. J Thorac Cardiovasc Surg. 2017;154:1047-51.

2. Castaneda AR, Norwood WI, Jonas RA, Colon SD, Sanders SP, Lang P Transposition of the great arteries and intact ventricular septum: anatomical repair in the neonate. Ann Thorac Surg. 1984;38:438-43.

3. Castaneda AR, Trusler GA, Paul MH, Blackstone EH, Kirklin JW. The early results of treatment of simple transposition in the current era. J Thorac Cardiovasc Surg. 1988;95:14-28.

https://doi.org/10.1016/j.jtcvs.2017.10.037

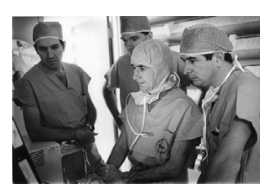

THE PITFALLS OF EARLY MORTALITY AS A MEASURE OF SURGICAL SUCCESS

Reply to the Editor:

We fully agree with Dr Jonas' assertion that early mortality is inadequate for assessing the success of a surgical procedure, especially in young individuals with congenital heart 